\title{
Integrative in silico and in vitro transcriptomics analysis revealed new IncRNAs related to intrinsic apoptotic genes in colorectal cancer
}

Fatemeh Akbari ${ }^{1}$, Maryam Peymani ${ }^{1 *}$, Ali Salehzadeh ${ }^{2^{*}}$ and Kamran Ghaedi ${ }^{3}$

\begin{abstract}
Background: Pathogenesis of colorectal cancer (CRC) is connected to deregulation of apoptosis while the effect of IncRNAs, as critical regulatory molecules, on this pathway is not clear well. The present study aimed to identify differential expression of genes and their related IncRNAs which are significantly associated with intrinsic apoptotic pathway in CRC.
\end{abstract}

Methods: The connection between CRC and apoptosis was investigated by literature reviews and the genes were enriched by using Enrichr. At the next step, differential expression of enriched genes were evaluated between normal and tumor populations in data sets and were downloaded from GEO. Then, meta-analysis and probe re-annotation were performed. For IncRNAs selection through the highest expression correlation with each of candidate genes, mRNA-IncRNA interaction of screened genes and all of IncRNAs were visualized using Cytoscape. Identified differential expression genes and IncRNAs were validated using TCGA-COAD and the obtained data were confirmed by in vitro studies in the presence of Ag@Glu-TSC nanoparticle as an apoptotic inducer. Cytotoxicity and apoptosis induction effect of Ag@Glu-TSC on Caco-2 cells was determined via MTT and Annexin V/PI, respectively. The expression of genes and IncRNAs were assayed in presence of mentioned nanoparticle. Finally, the expression level of desired genes and IncRNAs were proven in CRC tissues compared to adjacent normal tissues.

Results: After detection of 48 genes associated with intrinsic apoptosis in CRC according to literature, Enrichr screened 12 common genes involved in this pathway. Among them, 6 genes including BCL2, BCL2L11, BAD, CASP7, CASP9, and CYCS expression reduced in tumor tissue compared to normal according to meta-analysis studies and RNA-seq TCGA data. Afterwards, association of 8 IncRNAs comprising CDKN2B-AS1, LOC102724156, HAGLR, ABCC13, LOC101929340, LINC00675, FAM120AOS, PDCD4-AS1 with more than 5 candidate genes were identified. In vitro studies revealed that four selected InCRNAs including, CDKN2B-AS1, LOC102724156, HAGLR and FAM120AOS were significantly increased in the presence of in optimum concentration of Ag@Glu/TSC and decreased in tumor tissues versus adjacent normal tissues.

\footnotetext{
*Correspondence: m.peymani@iaushk.ac.ir; salehzadeh@iaurasht.ac.ir

${ }^{1}$ Department of Biology, Faculty of Basic Sciences, Shahrekord Branch,

Islamic Azad University, Shahrekord, Iran

${ }^{2}$ Department of Biology, Rasht Branch, Islamic Azad University, Rasht, Iran

Full list of author information is available at the end of the article
}

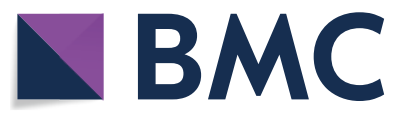

(c) The Author(s) 2020. This article is licensed under a Creative Commons Attribution 4.0 International License, which permits use, sharing, adaptation, distribution and reproduction in any medium or format, as long as you give appropriate credit to the original author(s) and the source, provide a link to the Creative Commons licence, and indicate if changes were made. The images or other third party material in this article are included in the article's Creative Commons licence, unless indicated otherwise in a credit line to the material. If material is not included in the article's Creative Commons licence and your intended use is not permitted by statutory regulation or exceeds the permitted use, you will need to obtain permission directly from the copyright holder. To view a copy of this licence, visit http://creativeco mmons.org/licenses/by/4.0/. The Creative Commons Public Domain Dedication waiver (http://creativecommons.org/publicdomain/ zero/1.0/) applies to the data made available in this article, unless otherwise stated in a credit line to the data. 
Conclusion: This study developed a new data mining method to screen differentially expressed IncRNAs which are involved in regulation of intrinsic apoptosis pathway in CRC quickly using published gene expression profiling microarrays. Moreover, we could validate a number of these regulators in the cellular and laboratory disease models.

Keywords: Colorectal cancer, Apoptosis, IncRNAs, Meta-analysis, RNA sequence

\section{Background}

Colorectal cancer (CRC) is the third and second common cancer among males and females, respectively $[1,2]$. In 2018, around 1.8 million new cases and about 86,100 deaths were reported cause of CRC. The prevalence of CRC is predicted to increase by $60 \%$ in 2020 with 101 million deaths and 202 million new cases [3].

Apoptosis, as a well-known kind of cell death, plays an important role in multicellular systems such as cancer. In colorectal tissue, the imbalance between cell proliferation and apoptosis typically yields tumor growth. Although the molecular mechanisms of cell division and apoptosis are similar in normal and tumor cells, these mechanisms are aberrantly regulated in tumor cells [4]. Recently, modulating effect on the biological behaviors of tumor cells is of interest for researchers to focus on noncoding RNAs (NcRNAs). In the group of NcRNAs, long noncoding RNAs (lncRNAs) gained much attention thanks to their significant regulatory effects on carcinogenesis and tumor development [5]. Indeed, IncRNAs are well-introduced as oncogenes or tumor suppressor genes by modulating cell proliferation and apoptosis [6].

Since the effect of specific lncRNAs on apoptosis mechanisms in CRC progress have been less studied, here we investigate lncRNAs, related to apoptosis genes in CRC tissues using Gene Expression Omnibus (GEO) data. Subsequently, RNA sequences data from The Cancer Genome Atlas (TCGA) database were used to confirm the GEO data. The expression changes of candidate genes and lncRNAs in the Caco-2 cell line in presence of Ag@Glu-TSC nanoparticles as an apoptotic agent were analyzed. Then expression of these identified lncRNAs in CRC tissues were evaluated and compared with adjacent normal tissues.

\section{Materials and methods}

\section{Data source and identification of differentially expressed} genes

A schematic process diagram of this study is presented in Fig. 1. The first important step in this study was selection of genes involved in intrinsic apoptosis in CRC based on literature review articles. Then gene enrichment was performed using Enrichr online database [7]. Selected genes from KEGG, WikiPathways and Reactome in Enrichr database were reported as genes involved in the internal apoptosis pathway with adjusted $P$-value $<0.05$. The significantly enriched gene pathways terms (adjusted $P$-value $<0.05)$ were summarized and visualized using the REVIGO web [8]. Raw gene expression data of the GEO series (GSE) including GSE8671, GSE9348, GSE18105, GSE20916, GSE21510 and GSE37364 datasets were downloaded from the National Center of Biotechnology Information GEO database (https://www.ncbi.nlm. nih.gov/gds/). These studies include tumor samples at different stages and adjacent non-tumor samples. These samples were used for expression analysis of candidate apoptosis genes. All studies were normalized by the same method, RMA method form limma package [9] of R. Principal component analysis (PCA) was performed using the prcomp function in the built-in $\mathrm{R}$ stats package (version 3.2.2). The first two PCs were visualized using the ggbplot package (version 0.55). Subsequently, we performed hierarchical cluster analysis using the $\mathrm{R}$ package heatmaps. Then studies were merged through probes and used SVA package (ComBat), to eliminate the batch effect and performed a meta-analysis of ten CRC transcriptome datasets using the bioinformatics approach [10]. Of course, for this meta-analysis phase, we added four additional datasets that contained only tumor samples to the study population. Finally In this examination, we identified differentially expression genes (DEGs) from GEO datasets. The DEGs were selected out according to the criteria: $\mid \log$ (fold change) $\mid<1.5$ and adj. $P$-val $<0.001$. A summary information of these datasets was shown in Table 1. All studies selected for meta-analysis of the same technology as the Affymetrix Human Genome U133 plus 2.0 Array were named GPL570 because this platform is repeatedly used and includes 22,277 common probe sets [11]. NCBI and UCSC databases were used to find genes related to the probes used in these studies. Moreover, LncPedia was applied to detect probes related to lncRNAs [12]. To identify DEGs that are played key role in colon tumorigenesis, we employed an integrative analysis of TCGA colon adenocarcinoma (TCGA-COAD) using TCGA biolinks package [13]. The sample size for CRC available at TCGA includes 480 cancerous and 41 normal samples. Then obtained data were normalized by the DEseq2 package.

\section{Co-expression network construction and analysis}

Map of mRNA-lncRNA interaction between DEGs and lncRNAs involved in apoptosis pathway, were visualized 
Searched NCBI for published article with CRC \& apoptosis pathway

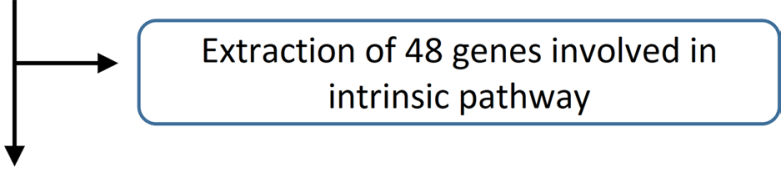

Gene enrichment analysis using Enrichr online database

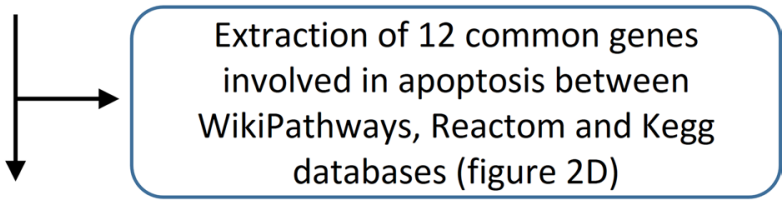

Downloaded 10 datasets from GEO with GPL570 platform and were done meta analysis and probe reanotation (NCBI and UCSC databases were used to identify genes and LncPedia was used to identify IncRNAs related to the probes) (Table 1)

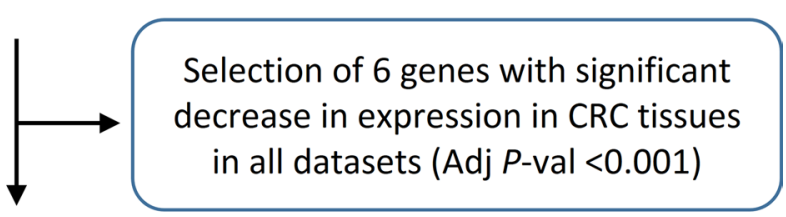

Expression analysis of these DEGs based on RNA-seq using TCGA-COAD

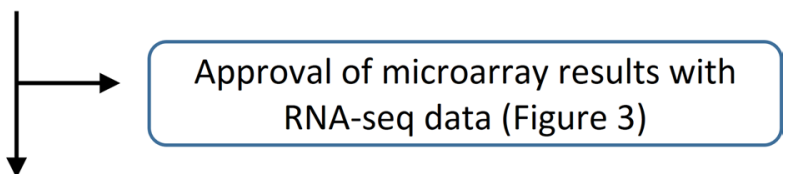

Visualized and analyzed mRNA-IncRNA interaction of screened DEGs and all of IncRNAs using Cytoscape
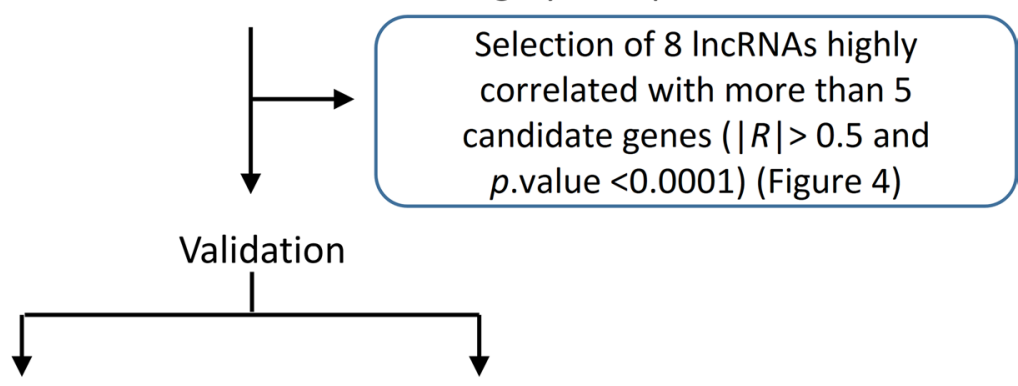

Comparison of the expression level of identified IncRNAs between CRC and
Assessment effects of

Ag@Glu/TSC on identified IncRNAs in

Caco-2 cell line adjacent normal tissues

Fig. 1 Study design flow chart. DEGs differential expression genes, GEO Gene Expression Omnibus, KEGG Kyoto Encyclopedia of Genes and Genomes, TCGA-COADThe Cancer Genome Atlas-Colorectal Adenocarcinoma, IncRNAs long non-coding RNAs, adj $P$-val adjusted $P$-value 
Table 1 Summary information of the datasets used in present study

\begin{tabular}{lccllc}
\hline GEO accession & $\begin{array}{l}\text { Number of normal } \\
\text { tissue }\end{array}$ & $\begin{array}{l}\text { Number of tumor } \\
\text { tissue }\end{array}$ & Platform & Country & Submission data \\
\hline GSE4107 & 10 & 12 & GPL570 & Singapore & 2006 \\
GSE8671 & 32 & GPL570 & Switzerland & 2007 \\
GSE9348 & 12 & 94 & GPL570 & Singapore & 2007 \\
GSE18105 & 17 & 123 & GPL570 & Japan & 2009 \\
GSE21510 & 17 & GPL570 & Japan & 2010 \\
GSE22598 & 17 & 35 & GPL570 & Japan & 2010 \\
GSE23878 & 24 & 17 & GPL570 & Saudi Arabia & 2010 \\
GSE32323 & 17 & 90 & GPL570 & Japan & 2011 \\
GSE33113 & 6 & 56 & GPL570 & Netherlands & 2011 \\
GSE37364 & 38 & 546 & Hungary & 2012 \\
Total & 198 & & & \\
\hline
\end{tabular}

and analyzed using Cytoscape software (version 3.4) [14]. The yFile application were also used to layout and enhance the visual appearance. The Pearson correlation coefficient of DEG-lncRNA pairs was calculated according to their expression value. The co-expressed DEG-lncRNA pairs with the absolute value of Pearson correlation coefficient $\geq 0.5$ were screened. Ultimately, lncRNAs were selected that were strongly correlated with the candidate genes in the intrinsic pathway.

\section{Synthesis of Ag@Glu-TSC nanoparticles}

To prepare the desired nanoparticle, $100 \mathrm{mg}$ glutamic acid was added to $50 \mathrm{ml}$ of $\mathrm{AgNo}_{3}$ and stirred for $30 \mathrm{~min}$ (solution 1). Then for providing the solution $2,20 \mathrm{mg}$ of $\mathrm{NaBH}_{4}$ was dissolved in $50 \mathrm{ml}$ of double distilled water and was added to solution 1 drop by drop and stirred for $3 \mathrm{~h}$. The produced precipitate, defines as Ag@Glu, was washed with ethanol and double distilled water several time, and then dried in $40{ }^{\circ} \mathrm{C}$ for $24 \mathrm{~h}$. Grafting the Thiosemicarbazide (TSC) on Ag@Glu was the next stage to generate Ag@Glu-TSC nanoparticle. For this stage, $60 \mathrm{ml}$ ethanol was added to the achieved precipitate, and sonicated for $20 \mathrm{~min}$. Then, $90 \mathrm{mg}$ of TSC was added to the resulted solution, and it was stirred for $24 \mathrm{~h}$. Ultimately, the final product was washed with ethanol and dried at $40{ }^{\circ} \mathrm{C}$ for $24 \mathrm{~h} \mathrm{[15].}$

\section{Characterization of synthesized Ag@Glu-TSC nanoparticles}

The synthesized Ag@Glu-TSC nanoparticle was characterized using Fourier transform infrared (FTIR) spectroscopy (Shimadzu, Japan). Size assessment and morphological properties of the Ag@Glu-TSC nanoparticles were performed using transmission electron microscope (TEM) (Zeiss 100KV model, Germany) and scanning electron microscope (SEM) (TESCAN MIRA3, Czech Republic). Also, the data from X-ray diffraction
(XRD) was measured using diffract meter (Philips X'Pert MPD, Netherlands). Finally, the energy-dispersive X-ray (EDX) spectrometry (TESCAN MIRA3, Czech Republic) was used to analyze the chemical composition of Ag@ Glu-TSC nanoparticle.

\section{Cell culture}

Caco-2 and HEK293 embryonic human cell lines as a colorectal cancer and a non-malignant cell line were obtained from National Cell Bank of Iran (Pasteur Institute, Tehran, Iran) and were used in this study. HEK293 and Caco-2 were cultured in Dulbecco's modified Eagle's medium (DMEM) or RPMI 1640 (Gibco, USA). These cell culture mediums were supplemented with $10 \%$ fetal bovine serum (FBS, Gibco, USA), penicillin (Gibco, USA) $(100 \mu \mathrm{g} / \mathrm{ml})$, streptomycin (Gibco, USA) $(100 \mu \mathrm{g} / \mathrm{ml})$, $2 \mathrm{mM} \mathrm{L}$-glutamine. Cells were incubated in a humidified atmosphere $5 \% \mathrm{CO}_{2}$ at $37^{\circ} \mathrm{C}$ incubators.

\section{Cell viability assay}

For evaluation of Ag@Glu-TSC nanoparticles cytotoxicity effect on Caco-2 and HEK293 cell lines, MTT assay 3-(4,5-dimethylthiazol-2yl)-2, 5-diphenyltetrazolium bromide (MTT) was performed. $1 \times 10^{4}$ cells were cultured in each well of the 96-well plates, and they were incubated for $24 \mathrm{~h}$ in presence of different concentrations of Ag@Glu-TSC nanoparticles (5, 25, 31, 92, 125, 250, and $500 \mu \mathrm{g} / \mathrm{ml})$. Then, $25 \mu \mathrm{g} / \mathrm{ml}$ MTT color solution was added to each well and after $4 \mathrm{~h}$ the solution over each well was removed and dimethyl sulfoxide (DMSO) was added to dissolve formazan crystals. At least, optical density at $570 \mathrm{~nm}$ was measured using an ELISA micro plate reader. The IC50 values of cells were calculated by the following formula: 
(\%) inhibition $=\frac{\text { Abs of control }- \text { Abs of test }}{\text { Abs of control }} \times 100$.

Flow cytometry analysis of apoptosis/necrosis

Cells were permitted to adhere and proliferate for $24 \mathrm{~h}$ former to exposure to nanoparticle. The incubated cells were treated with IC50 concentration of Ag@Glu-TSC nanoparticles and maintained for an additional $24 \mathrm{~h}$. The cells were separated from the wells due to treatment with trypsin and centrifugation, washed with PBS and then stained with $10 \mu \mathrm{l}$ annexin-V-FLUOS and $5 \mu \mathrm{l}$ propidium iodide (PI) based on the manufacturer protocol (Roch, Germany). The number of apoptotic and necrotic cells was assessed by flow cytometry device (Partec, Germany) and compared between treated and untreated Caco-2 cells.

\section{Sample collection, RNA extraction, CDNA synthesis and RT-qPCR}

This study was approved by the Biomedical Ethics Committee of the Islamic Azad University of Shahrekord and also complies with the Ethics Code of IR.IAU.SHK. REC.1398.044. In the main-time all participants signed informed consent. All methods have been accomplished according to related protocols. Twenty tissue samples of intestinal section patients with CRC who were approved by a professional pathologist following Iran National Tumor Bank's inspection and principles Clinical information of these samples was shown in Table 2 Also in this study, cultured cells were collected for expression of genes assay. Total RNA extraction from culture cells, tumor and adjacent normal colorectal tissue was performed with TRIzol (Sigma-Aldrich, Germany) kits, according to the manufacturer's instruction. After determination of RNA quality, RNA samples were treated with RNase-free DNase I (Sinaclon, IRAN) according to protocol. cDNA synthesis was done by cDNA synthesis kit (Biofact, Korea). QPCR was done in Roche real-time PCR systems by using $10 \mu \mathrm{l}$ SYBR Green PCR Master Mix (Takara, Japan), $10 \mathrm{pmol} / \mu \mathrm{l}$ of each primer, and $50 \mathrm{ng}$ cDNA in a final volume of $20 \mu \mathrm{l}$ for each reaction, Expression samples was normalized to $\beta$-ACTIN as an internal control. All measurements were carried out in triplicate and data were analyzed by $\Delta \mathrm{Ct}$ method. The specific primers for each mRNA and lncRNA which are listed in Table 3 were designed using Beacon Designer (https://www.ncbi.nlm.nih.gov/tools/primerblast/). (version 7.2, USA) obtained from Metabion Company (Germany) and confirmed with "NCBI Primer BLAST" (https ://www.ncbi.nlm.nih.gov/tools/primerblast/).
Table 2 Patients' demographic and clinical information $(\mathbf{n}=\mathbf{2 0})$

\begin{tabular}{|c|c|}
\hline Variables & Number \\
\hline \multicolumn{2}{|l|}{ Age } \\
\hline$<50$ & 16 \\
\hline$\geq 50$ & 4 \\
\hline \multicolumn{2}{|l|}{ Sex } \\
\hline Male & 16 \\
\hline Female & 4 \\
\hline \multicolumn{2}{|l|}{ TNM stage } \\
\hline 1 & 2 \\
\hline$\|$ & 8 \\
\hline III & 8 \\
\hline IV & 2 \\
\hline \multicolumn{2}{|l|}{ Grade } \\
\hline 1 & 4 \\
\hline$\|$ & 11 \\
\hline III & 2 \\
\hline IV & 2 \\
\hline Unknown & 1 \\
\hline \multicolumn{2}{|l|}{ Tumor size $(\mathrm{cm})$} \\
\hline$<5$ & 6 \\
\hline$>5$ & 14 \\
\hline \multicolumn{2}{|l|}{ Smoking } \\
\hline Smoker & 3 \\
\hline Non-smoker & 17 \\
\hline
\end{tabular}

\section{Statistical analysis}

All data were expressed (mentioned) as the mean \pm standard deviation (SD). Statistical analysis and curve fitting were carried out (accomplished) by using SPSS 20.0 and GraphPad Prism 8.0 (GraphPad Software, San Diego, CA). Based on the test condition, Student's t-tests or Mann-Whitney U-test were used to determine the differences between desired groups. All the data were considered significant when the $P<0.05$ and with a $95 \%$ corresponding confidence level.

\section{Results}

Preparation of a gene list involve in intrinsic apoptosis pathway in CRC

Based on literature review [16-31], 48 genes were identified in related to the apoptosis pathway. This gene list is shown in Additional file 1: Table S1. We further examined the putative biological function of these genes by using pathway enrichment analysis (Fig. 2a-c). Our data revealed that these genes were significantly enriched in apoptosis pathway. The list of overlapped genes from all three databases, as important genes in desire pathway in CRC, are shown in the Fig. 2d. Moreover, the results of 
Table 3 The specific primer sequences for selected IncRNAs and mRNAs

\begin{tabular}{|c|c|c|c|}
\hline Gene name & Primer sequence $\left(5^{\prime}\right.$ to $\left.>3^{\prime}\right)$ & Annealing $\left({ }^{\circ} \mathrm{C}\right)$ & $\begin{array}{l}\text { Length } \\
\text { product } \\
\text { (bp) }\end{array}$ \\
\hline HAGLR (Inc-AC009336.1-2) & $\begin{array}{l}\text { CAGACTCAGCAGATACTC } \\
\text { TCATCTCCTCTTCCTACC }\end{array}$ & 62 & 204 \\
\hline CDKN2B-AS1 (Inc-MTAP-1) & $\begin{array}{l}\text { TATTCCTGGCTCCCCTCGTC } \\
\text { TGACCTCGCTTTCCTTTCTTCC }\end{array}$ & 61 & 185 \\
\hline PDCD4-AS1 (Inc-BBIP1-1) & $\begin{array}{l}\text { GTCCTACCTCCCCCACTAAC } \\
\text { TGGAACAATCCCTCCCACA }\end{array}$ & 58 & 181 \\
\hline LINC00675 (Inc-PIRT-1) & $\begin{array}{l}\text { TTAGAACCAACCACAAGCACCA } \\
\text { AGCCAGTGAGGAGAAATAGCAAC }\end{array}$ & 60 & 88 \\
\hline FAM120AOS (nc-FAM120AOS-4) & $\begin{array}{l}\text { GCAGAACACCAAAGGAGACC } \\
\text { ATTTTTGCATCAGCCCAAAG }\end{array}$ & 60 & 195 \\
\hline LOC101929340 (Inc-NRGN-1) & $\begin{array}{l}\text { TCAACCAACAGGCATCAGAA } \\
\text { CCGCAAATCCAGGTAAGAAC }\end{array}$ & 58 & 143 \\
\hline ABCC13 (Inc-RBM11-5) & $\begin{array}{l}\text { AGGAATCAAGAGAGGCAAAAAGC } \\
\text { GAGTGGGCTAGTGAAGGACAA }\end{array}$ & 59 & 162 \\
\hline LOC102724156 (Inc-CDK20-8) & $\begin{array}{l}\text { GGACACCCTAGAGGCAGAGA } \\
\text { TCAAACTTGTGTGCTGAAGAGA }\end{array}$ & 62 & 150 \\
\hline CYCS & $\begin{array}{l}\text { GGCGGCTGTGTAAGAGTATCCA } \\
\text { AACCTTACCCCAGTGGTGCTC }\end{array}$ & 60 & 192 \\
\hline CASP9 & $\begin{array}{l}\text { AACCTTACCCCAGTGGTGCTC } \\
\text { ATCTGCATTTCCCCTCAAACTCTCA }\end{array}$ & 62 & 138 \\
\hline $\mathrm{BCL} 2$ & $\begin{array}{l}\text { AACATCGCCCTGTGGATGACT } \\
\text { GGCAGGCATGTTGACTTCACTT }\end{array}$ & 62 & 223 \\
\hline CASP7 & $\begin{array}{l}\text { GGACCGAGTGCCCACTTATC } \\
\text { TCGCTTTGTCGAAGTTCTTGTT }\end{array}$ & 60 & 89 \\
\hline BAD & $\begin{array}{l}\text { GGAGGATGAGTGACGAGTTTG } \\
\text { TTCGGGATGTGGAGCGAAG }\end{array}$ & 60 & 184 \\
\hline GAPDH & $\begin{array}{l}\text { TGAAGTCGCAGGAGACAACC } \\
\text { TGCCGCCTGGAGAAACC }\end{array}$ & 60 & 121 \\
\hline
\end{tabular}

the Enrichr analysis are summarized in Table 4. Most of these enriched pathways are related to apoptosis. These identified pathways are downstream or upstream of the apoptotic pathway and the main result of these pathways is cell death.

\section{Expression trends of selected genes in GEO is as similar as TCGA database}

As shown in Additional file 2: Figure S1A-F, a total of 6 GEO series (GSE) in the GEO database were elicited for the present study according to the inclusion principle. By utilizing heatmap and PCA, the quality control results of two studies from chosen datasets were obtained (Additional file 3: Figure S2A-D). The PCA results were appropriate for distinguishing between tumor and normal tissue samples. We evaluated the expression changes of candidate genes between CRC and normal tissue by the meta-analysis of $6 \mathrm{GEO}$ datasets. Then the genes were selected that their expression levels were significantly down regulated in all cancerous tissues compared with adjacent non-tumor tissues with adj. $P$-val $<0.001$. Finally, these analysis showed that six genes including BCL2,
BCL2L11, BAD, CASP7, CASP9, and CYCS significantly had a reduced expression level in all these datasets. The accuracy confirmation of candidate genes in meta-analysis was examined by performing analysis of RNA-seq data available at TCGA database. As shown in Fig. 3a-f, the expression of the nominate genes between CRC tumor samples and normal colon tissue was assayed in the RNA-seq data and these data confirmed the microarray results.

\section{Co-expression network analysis of differently expressed IncRNAs and mRNAs in intrinsic apoptosis pathway}

Pearson correlation coefficient was calculated between each candidate gene in apoptotic pathway (including BCL2, BCL2L11, BAD, CASP7, CASP9 and CYCS) and all lncRNAs in GPL570 chip. For this phase of the metaanalysis study, four additional datasets containing only tumor colorectal samples were added to the study. The lncRNAs with the highest expression correlation with each of the candidate genes $(|\mathrm{R}|>0.5$ and $P$ value $<0.0001)$ were selected for co-expression network construction. The network of apoptotic pathway genes that are reduced 


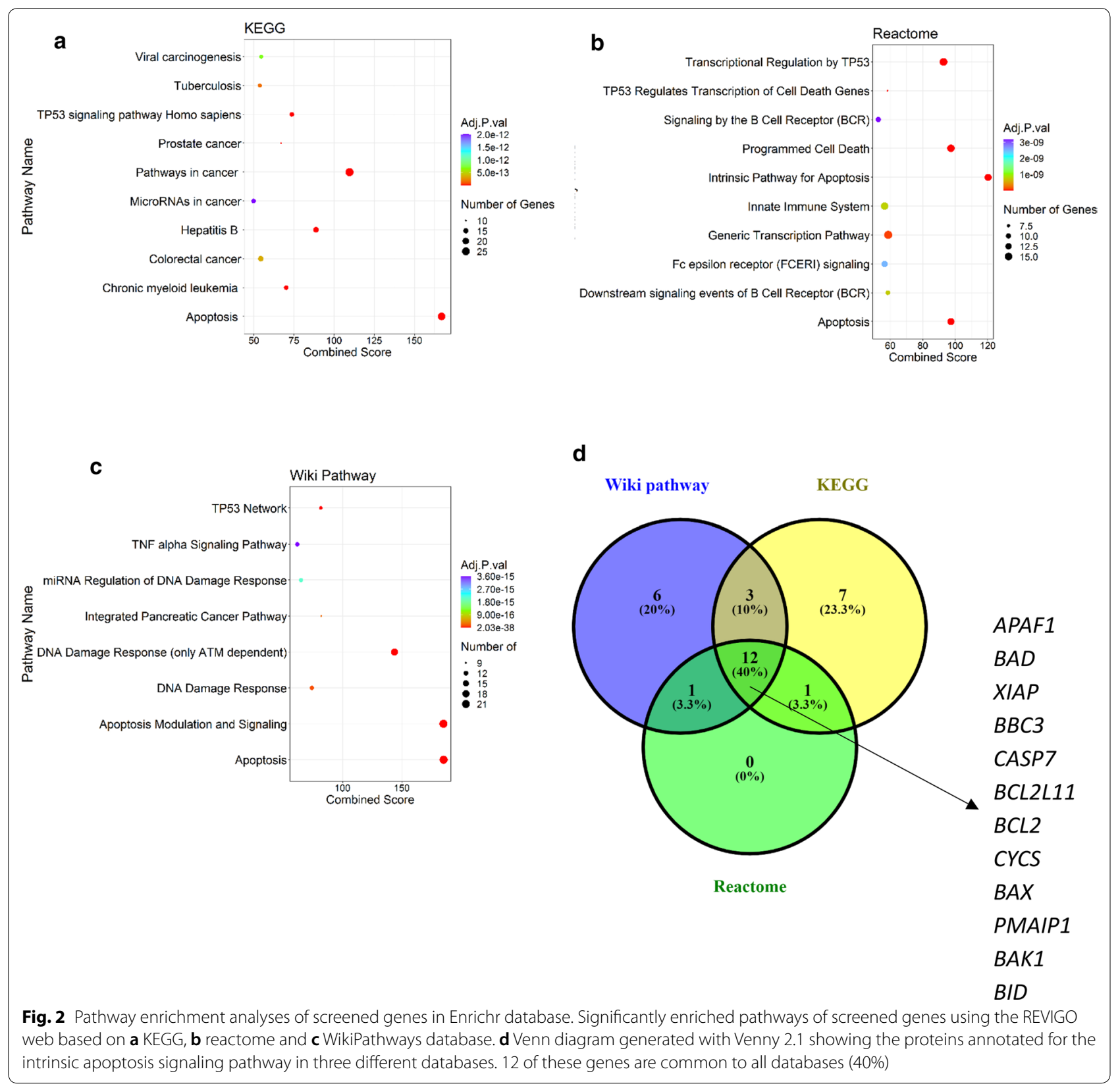

Table 4 Summarized of the Enrichr analysis results

\begin{tabular}{ll}
\hline Database & Gene names \\
\hline KEGG pathway & HRK-APAF1-BCL2A1-BAD-XIAP-FOS-NFKBI-RELA-BBC3-CASPS9-NRAS-CASP7-BCL2L11- \\
& AKT3-BCL2-CYCS-BAX-PMAIP1-FAS-BAK1-RAFI-BID-HRAS \\
WikiPathways & HRK-APAF1-BCL2A-CDKN2A-BIK-BAD-XIAP-FOS-NFKB1-BBC3-CASP9-CASP7-BCL2L11- \\
& BCL2-CYCS-BAX-PMAIP1-FAS-BAK1-BID-BCL2L2-BOK \\
Reactome pathway & APAF1-BAD-XIAP-BBC3-CASP9-CASP7-BCL2L11-AKT3-BCL2-CYCS-BAX-PMAIP1-BAK1-BID \\
Overlapped genes of databases & APAF1-BAD-XIAP-BBC3-CASP7-BCL2L11-BCL2-CYCS-BAX-PMAIP1-BAK1-BID
\end{tabular}




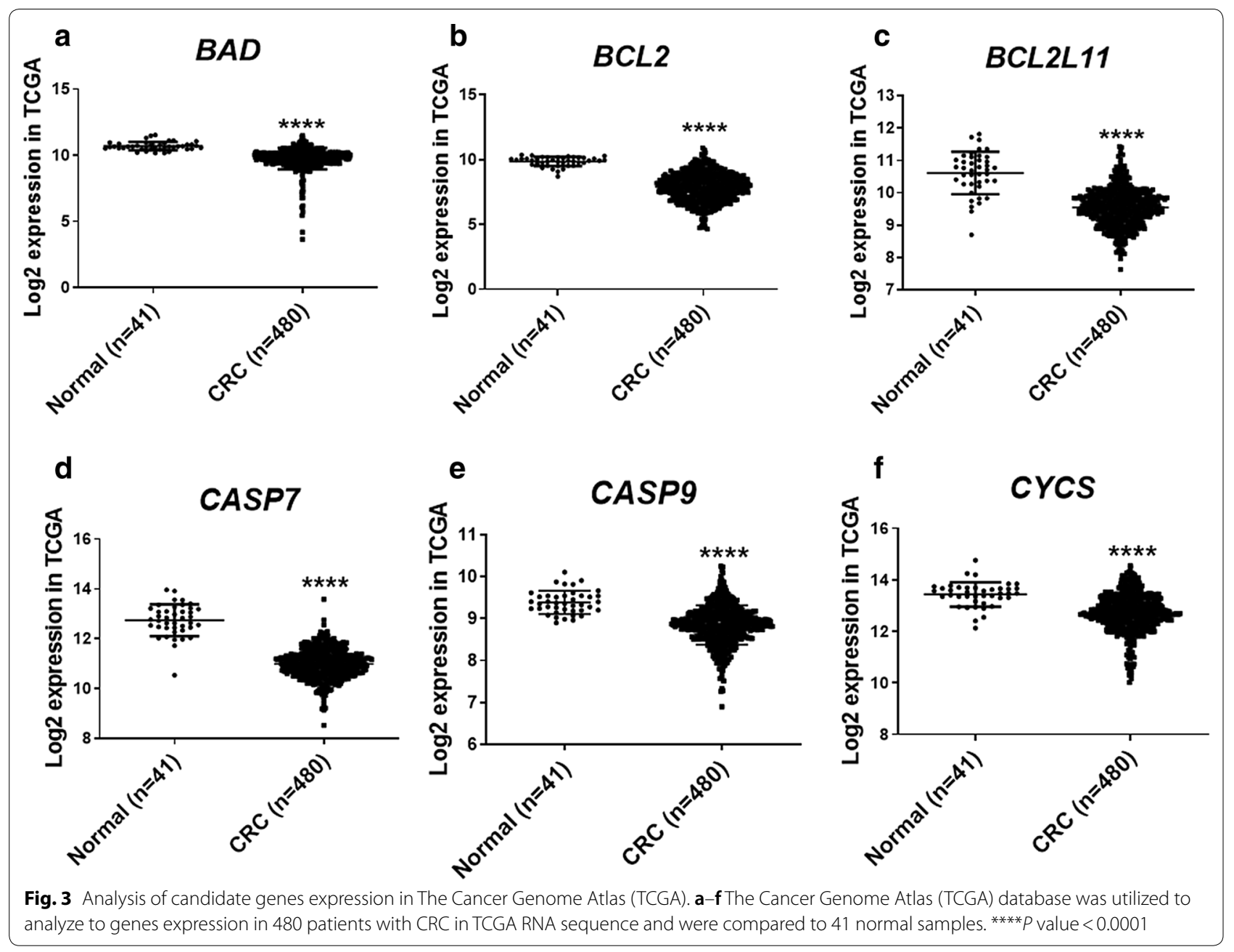

in cancer tissue and the lncRNAs that have a significant expression relation with these genes, are displayed in the Fig. 3. As shown in Fig. 4, a total of 105 lncRNAs and 6 candidate mRNAs were included in this network. Among them, CDKN2B-AS1, LOC102724156, HAGLR, ABCC13, LOC101929340, LINC00675, FAM120AOS and PDCD4$A S 1$ were identified as key lncRNAs in this network which associated with more than 5 candidate genes and were presented in Additional file 4: Table S2.

\section{Characterization of Ag@Glu-TSC}

The synthesis process of Ag@Glu-TSC nanoparticles is illustrated in Fig. 5a. First of all, functionalization of Ag nanoparticles was done with glutamic acid. The produced nanoparticles (Ag@GA) were then conjugated with bioreactive TSC moiety through covalent bonding of terminal amino groups of TSC and carboxylic groups of the glutamic acid. FTIR spectrum of synthesized Ag@GluTSC nanoparticles is exhibited in Fig. 5b. Robust bands at 3370 and $1640 \mathrm{~cm}^{-1}$ present the vibrational modes of water molecules adsorbed on the surface of the synthesized materials. The bands at about 2939 and $2860 \mathrm{~cm}^{-1}$ can be referred to the asymmetric $\mathrm{CH}_{2}$ stretching bands [32]. The bands at around the 800 can be recognized to the $\mathrm{cm}^{-1} \mathrm{~m}(\mathrm{C}=\mathrm{S})$ and the band observed at $1281 \mathrm{~cm}^{-1}$ can be attributed to the $\mathrm{m}(\mathrm{C}-\mathrm{N})$ [33]. Besides, the amide formation was proved with an amide bending vibration at around $1528 \mathrm{~cm}^{-1}$. This pick suggests the TSC attachment on the Ag@Glu nanoparticles, is formed via amide connection between GA and TSC. The crystal structure of synthesized nanoparticle was determined using XRD (Fig. 5c). The peaks of Ag@Glu-TSC nanoparticles in $2 \theta$ degree $38.28^{\circ}, 44.04^{\circ}, 64.34^{\circ}$ and $77.28^{\circ}$ correspond to (111), (200), (220) and (311) Bragg's reflection of $\mathrm{Ag}$ (JCPDS card no. 04-0783). The sharp peaks had a good match with JCPDS (08-0726) file for TSC. Moreover, high intensity and sharpness of XRD peaks show great quality of the synthesized nanoparticles. The presence of silver and other compositional elements in the final structure were confirmed by using EDX spectroscopy (Fig. 5d). 


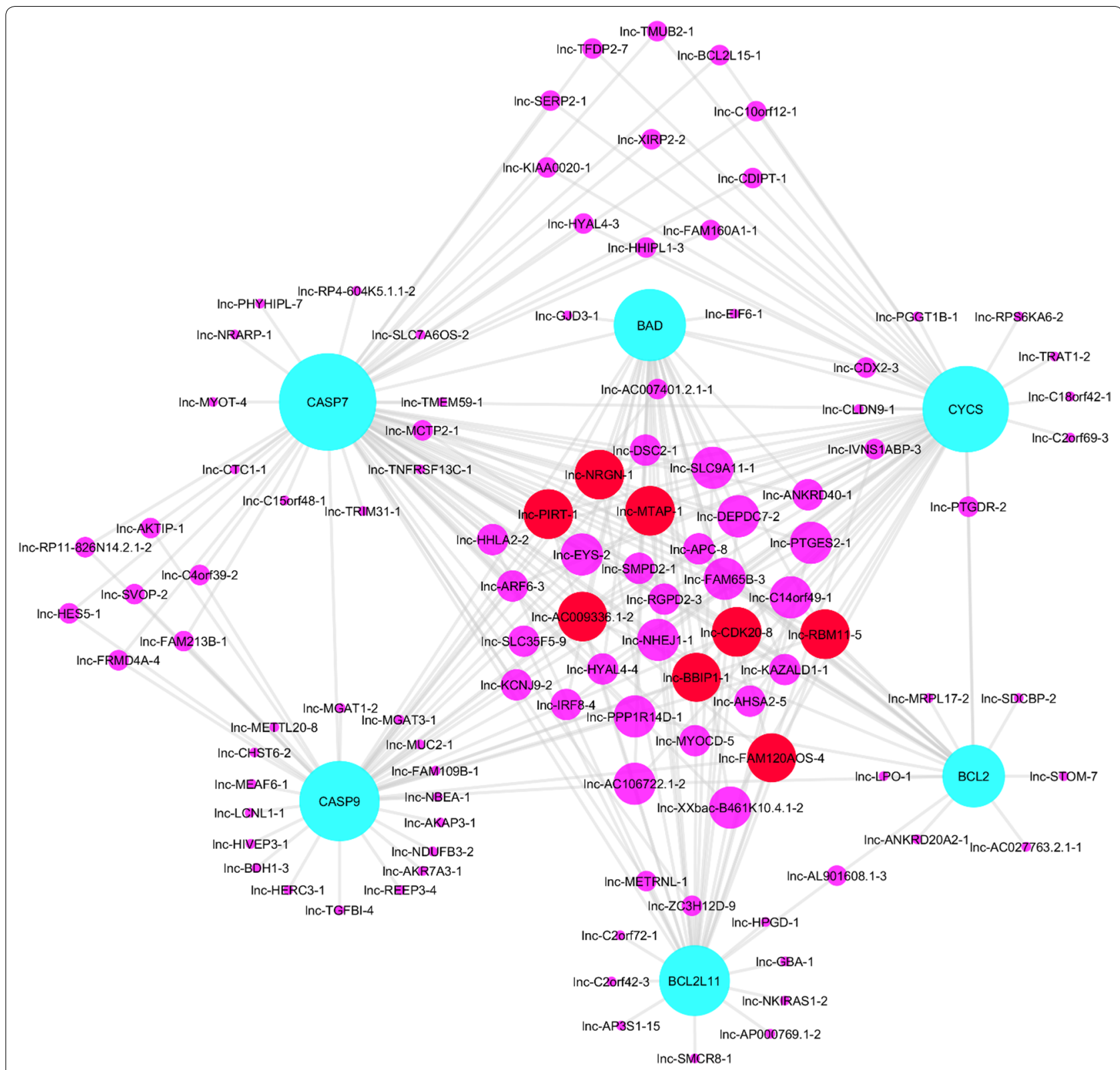

Fig. 4 Construction of IncRNA-mRNA co-expression networks. LncRNA-mRNA co-expression networks of all 105 differentially expressed IncRNAs and 6 mRNAs with |Pearson correlation coefficient $\geq 0.5$ and $P$ value $<0.0001 \mid$. Red circles represents IncRNA with highly correlation and purple represents IncRNAs with poor correlation with candidate mRNAs. IncRNA long non-coding RNA

The elements of $\mathrm{O}, \mathrm{N}, \mathrm{C}, \mathrm{K}$, and $\mathrm{S}$ were characterized in synthesized nanoparticle (Table 5). Moreover, the morphology and size of Ag@Glu-TSC nanoparticles were evaluated using electron microscopy. SEM image of manufactured nanoparticles depicts a spherical shape according to Fig. 5e, f. Additionally, the TEM image, measured the mean size of the Ag@Glu-TSC nanoparticles approximately $50 \mathrm{~nm}$ (Fig. 5g).

\section{Apoptosis induction in presence of Ag@Glu-TS nanoparticles}

Cellular toxicity of various concentrations of Ag@GluTSC nanoparticles on Caco-2 and non-malignant HEK293 cell lines was assessed via MTT assay technique. The concentration of $500 \mu \mathrm{g} / \mathrm{ml}$ of Ag@Glu-TSC nanoparticles showed the maximum cell growth inhibition in Caco-2 cells $(P<0.001)$. IC50 nanoparticle concentration 
(See figure on next page.)

Fig. 5 Synthesis and characterization of Ag@Glu-TSC. a Schematic diagram of the synthesis of Ag@Glu-TSC. b FTIR picks of nanoparticle. c XRD pattern of silver nanoparticles synthesized. $\mathbf{d}$ EDX spectrum of synthesized silver nanoparticles. e, $\mathbf{f}$ SEM images of nanoparticle. $\mathbf{g}$ TEM image of nanoparticle. FTIR Fourier-transform infrared spectroscopy, XRD x-ray diffraction, EDX energy dispersive x-ray, SEM scanning electron microscopy, TEM transmission electron microscopy

was calculated as 247.22 and $380 \mu \mathrm{g} / \mathrm{ml}$ for Caco-2 and HEK-293 cells, respectively, (Fig. 6a, b).

Moreover, dot plots of Annexin V/PI staining are shown in Fig. 6c, d. Exposure of Caco-2 cells with IC50 concentration of Ag@Glu-TSC exhibited about 44.8\% early stage of apoptosis and $33.4 \%$ late stage of apoptosis. In comparison, $0.45 \%$ of untreated cells were in early stage of apoptosis and $0.36 \%$ in late stage of apoptosis (Fig. 6c, d).

\section{CDKN2B-AS1, LOC102724156, HAGLR and FAM120AOS as selected IncRNAs up-regulated as well as BAD, CASP9 and CYCS in cancer cell and tissues}

In order to evaluate alterations in candidate genes and lncRNAs expression, RT-qPCR was performed, representing that $B A D, C Y C S, C A S P 9, C D K N 2 B-A S 1$, LOC102724156, HAGLR and FAM120AOS levels were significantly increased following treatment with $247.22 \mu \mathrm{g} / \mathrm{ml}$ Ag@Glu-TS for 24 h, in comparison with untreated cells and DMSO treatment as control groups (Fig. 7).

Since expression patterns of four lncRNAs and three candidate genes were similar in cellular model, we hypothesized that IncRNAs expression is altered in tumor tissues. As depicted in Fig. 8a, the expression level of mentioned lncRNAs decreased in tumor tissues versus adjacent normal tissues CRC patients significantly and confirmed data of cell culture model. Moreover, expression data of CDKN2B-AS1, HAGLR and FAM120AOS were validated with RNA sequence data obtained TCGA source (Fig. $8 \mathrm{~b}$ ) however there was not any expression data about $L O C 102724156$ in this database.

\section{Discussion}

Apoptosis is a form of programmed cell death that leads to the elimination of damaged and unwanted cells and has a critical function in both normal and pathological processes [34]. Apoptotic cells show various biochemical modifications such as DNA and protein breakdown, caspase activation, membrane blebbing and phagocytic recognition that together result in the distinctive structural pathology [35]. Activation of a group of cysteine proteases called "caspases "appears to be important during apoptosis mechanism. Caspases have been widely considered by their known acts in apoptosis (caspase-3,
$-6,-7,-8$, and -9 in mammals) and among them, Caspase 8 is known as an initiator caspase which is able to activate the other caspases [36]. Most apoptotic programs fall into either the extrinsic or intrinsic class. Noticeably, intrinsic apoptosis is also known as mitochondrial apoptosis because it depends on factors released from the mitochondria and can active by a vast array of cellular stresses and developmental signals that finally results in cytochrome c release from the mitochondria and apoptosome formation, subsequently. The extrinsic apoptosis route is activated through the binding of a ligand to a death receptor, which in turn leads, under the support of the adapter proteins (FADD/TRADD), to recruitment, dimerization, and activation of caspase- 8 . At the next step, active caspase-8 either initiates apoptosis directly by cleaving and through activating executioner caspase $(-3,-6,-7)$, or activates the intrinsic apoptotic pathway thereby cleavage of BID to create effective cell death [37]. This process is rigidly controlled by BCL-2 family proteins. $\mathrm{BCL}-2$ proteins classify into two groups: The pro-apoptotic proteins including: $\mathrm{BAX}, \mathrm{BAK}$ and BAD, BCL-XS, BID, BIK, BIM and HRK and the antiapoptotic proteins containing: BCL-2, BCL-XL, BCL-W, BF1-1 and MCF-1 [38]. Although it has been demonstrated that apoptosis can prevent of tumor progression, there is a wide range of means to inhibit this kind of cell death. Tumor-suppressor genes and oncogenes are commonly associated with apoptosis and CRC development. It appears that all routine remedies mostly operate via intrinsic apoptosis pathway and drug resistance can be the result of the failure of this way [39]. Till now, all methods which target the intrinsic apoptosis pathway were focused on BCL-2 family proteins. The current study aimed to identify DEGs that are significantly associated with the apoptotic pathway, and exploring the related lncRNAs at the whole genome level characteristic of CRC. IncRNAs have been established as useful biomarkers in CRC, and may be effective in early cancer detection and inhibition of CRC developing into malignancies. Furthermore, they may also act in early treatment. In addition the detection of single lncRNA alterations by PCR-based methods, genome-wide analysis can be accomplished by RNA-Seq and microarrays. Convinced lncRNAs connected to apoptotic pathway were previously analyzed in colorectal diseases. However, the main attention of previous studies was limited to one or two 

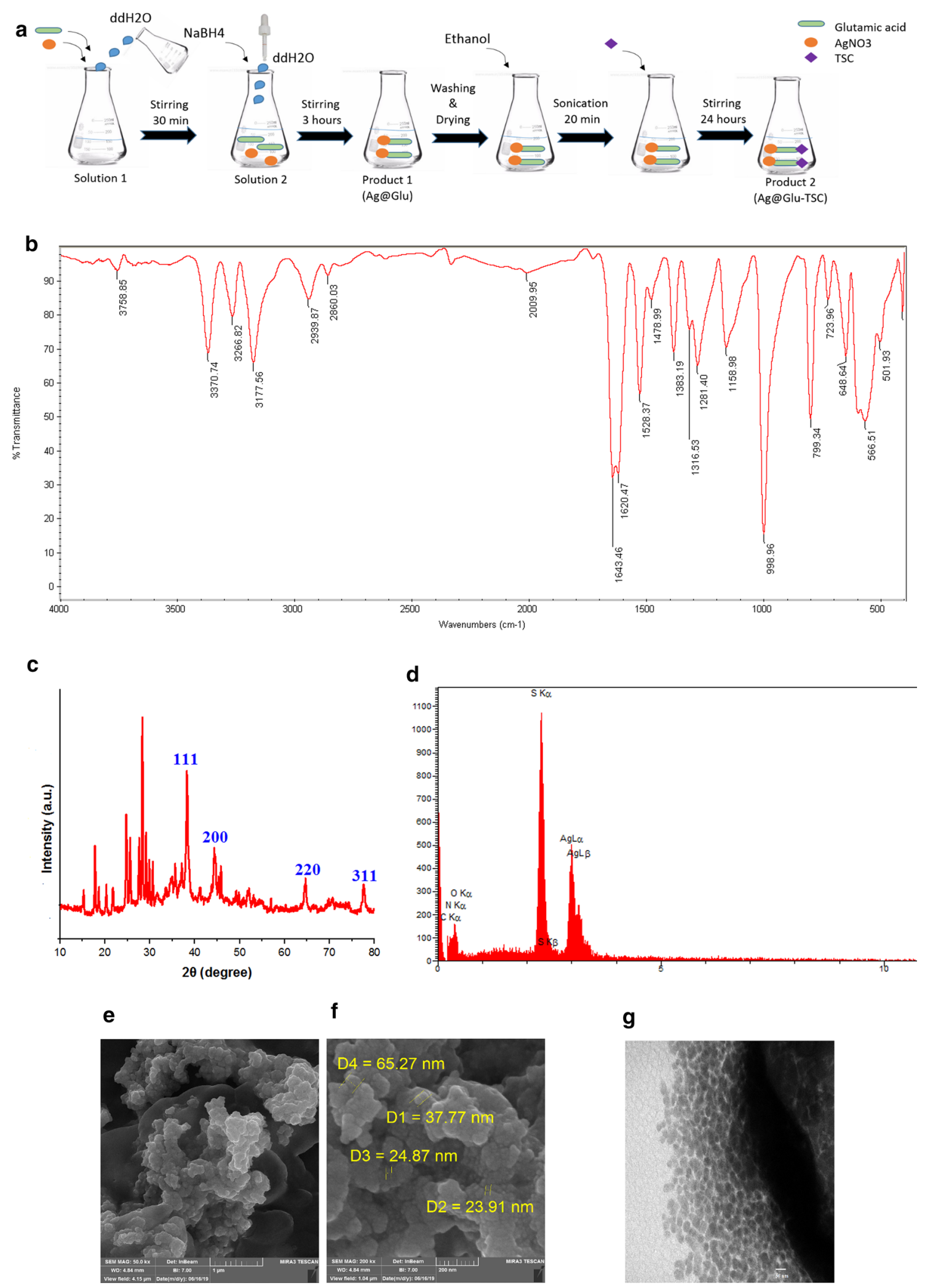

g 
Table 5 Results of EDX analysis of Ag@Glu-TSC nanoparticles

\begin{tabular}{lllccl}
\hline Elements & $\mathbf{K}$ & $\mathbf{K r}$ & Weight \% & Atomic \% & ZAF \\
\hline $\mathrm{C}$ & 0.0831 & 0.0404 & 16.84 & 27.59 & 0.2399 \\
$\mathrm{~N}$ & 0.1923 & 0.0934 & 40.73 & 57.25 & 0.2293 \\
$\mathrm{O}$ & 0.0000 & 0.0000 & 0.00 & 0.00 & 0.1270 \\
$\mathrm{~S}$ & 0.3283 & 0.1595 & 17.19 & 10.55 & 0.9280 \\
Ag & 0.3963 & 0.1925 & 25.24 & 4.61 & 0.7628 \\
Total & 1.0000 & 0.4859 & 100.00 & 100.00 & \\
\hline
\end{tabular}

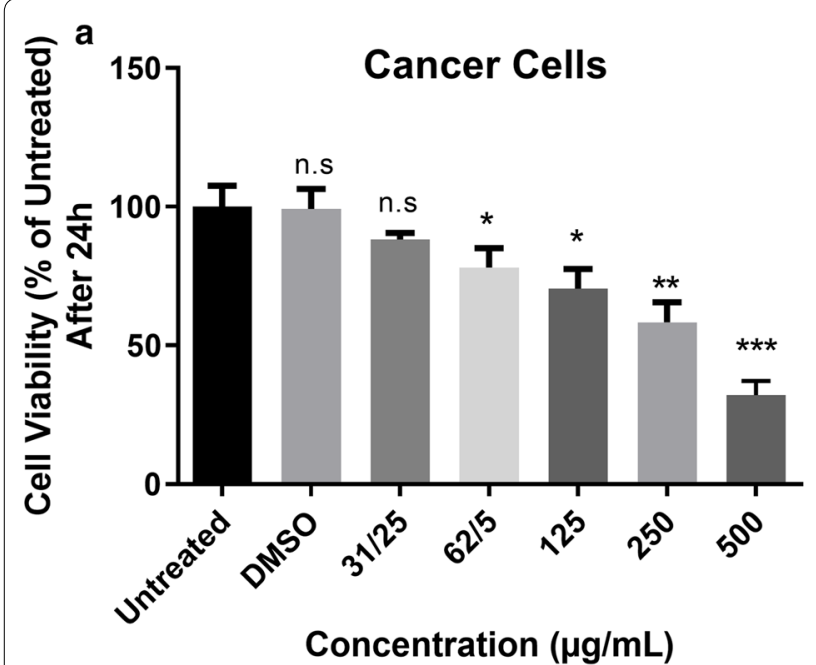

Caco2 cells

c) (Ag@Glu-TSC treatment)

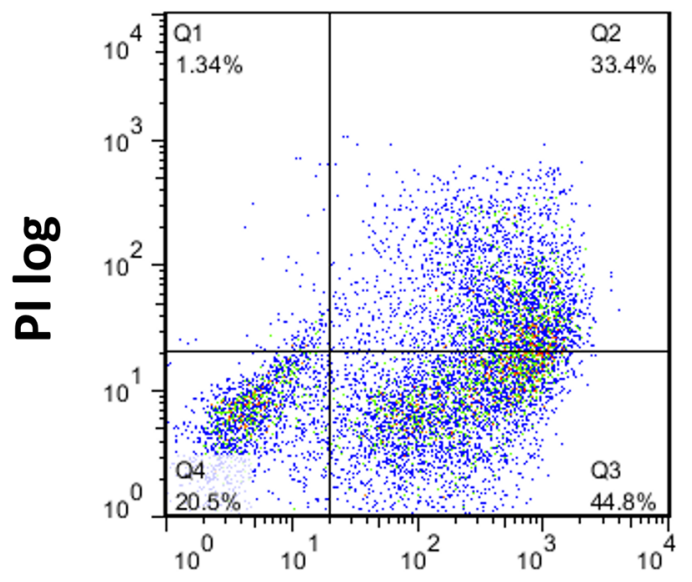

Annexin-V-FITC log
lncRNAs [40]. In this research, for the first time, we could identify putative lncRNAs involved in regulation of intrinsic apoptosis genes by insertion of CRC cases in a genome-wide lncRNA expression analysis. In this regard, we investigated all CRC expression profiling data in GEO database. At the next step, ten microarrays were selected, which 6 of them were included CRC cases and normal tissues, and 4 datasets were contained CRC tissues only. Based on datasets Meta-analysis in the current study, 105 candidate lncRNAs were differentially expressed along the CRC in related to 6 genes of intrinsic apoptosis pathway that could be validated on independent microarray
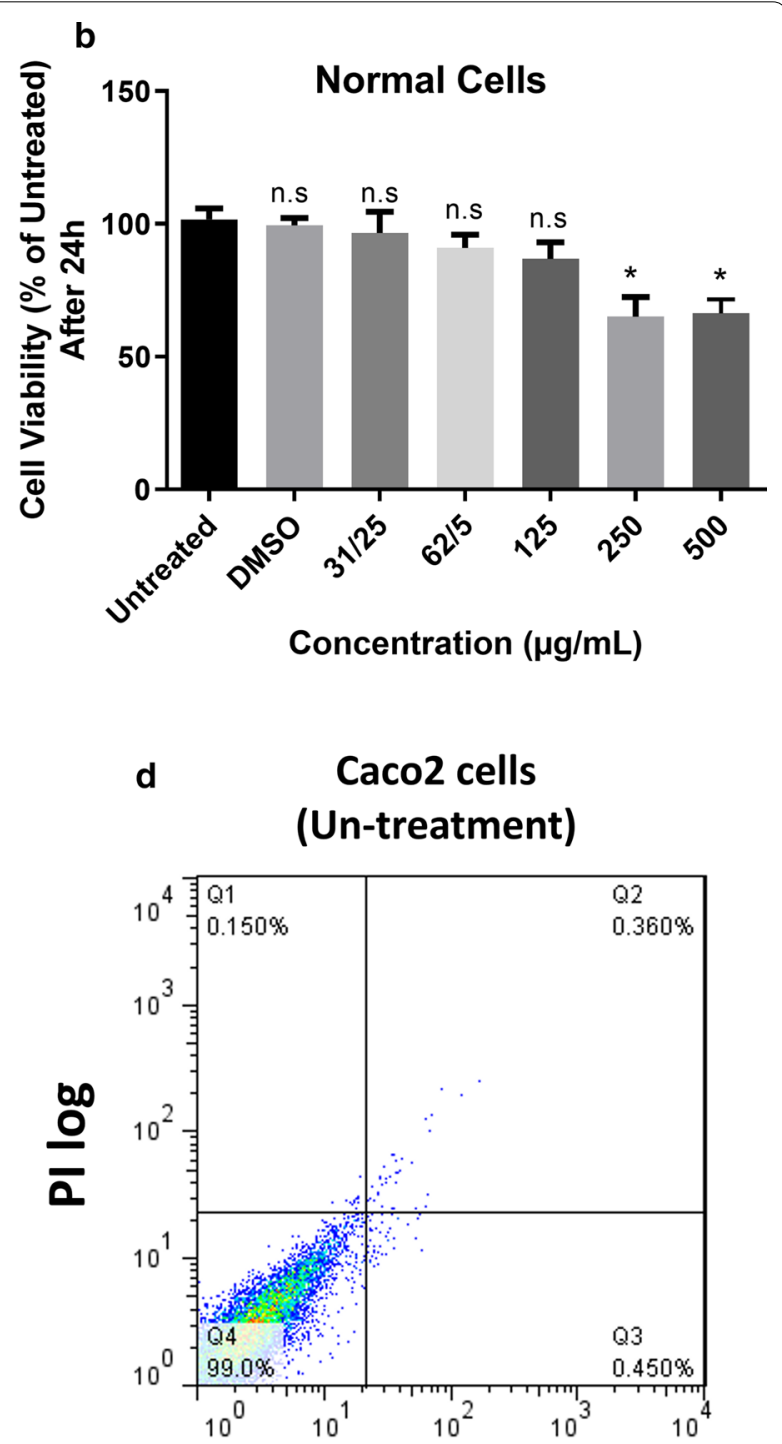

Annexin-V-FITC log

Fig. 6 Direct effects of Ag@Glu-TSC on cell viability and apoptosis of Caco2 cells. a Dose-dependent effects of nanoparticles on cancer cells viability and normal cells after $24 \mathrm{~h}$. $\mathbf{b}$ Comparison of nanoparticle administration with $247.22 \mathrm{\mu g} / \mathrm{ml}$ on the apoptosis in Caco-2 cells between treated and untreated group using flow cytometry. ${ }^{*} P$ value $<0.05$, ${ }^{* *} P$ value $<0.01$ and ${ }^{* * *} P$ value $<0.0001$ 


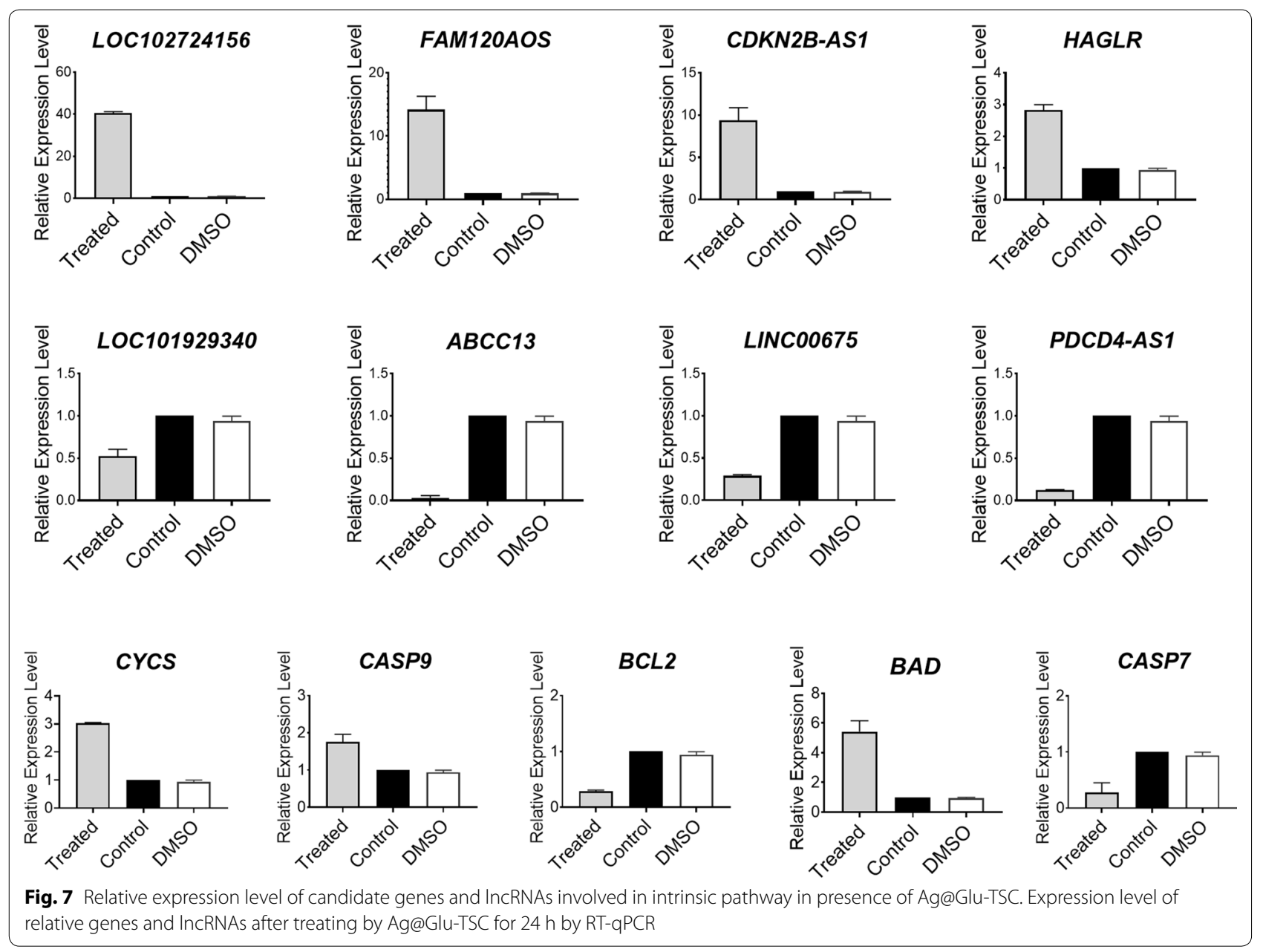

results and TCGA COAD dataset. Among these 105 lncRNAs, CDKN2B-AS1, LOC102724156, HAGLR, ABCC13, LOC101929340, LINC00675, FAM120AOS, PLEKHA7 and PDCD4-AS1 were recognized as key lncRNAs in this network which are associated with more than 5 candidate genes according to co-expression network analysis using cytoscape. Although, comprehensive analysis of large-scale samples for evaluating of the differentially expressed apoptosis genes and lncRNAs in CRC patients were performed, it seems that these findings need to be evaluated in CRC tissues and in vitro cell model. For this purpose, Caco- 2 cell line was selected and Ag@Glu-TSC was used as an apoptosis inducer agent in these cells on the one hand, Shandiz et al. [15] showed the novel Ag@Glu-TSC nanoparticles are able to inhibit the proliferation of MCF7 cancer cell line. In the present paper the apoptotic effect of Ag@Glu-TSC on Caco-2 cell line was proved and the expression of $B A D$ and $C Y C S$ were significantly increased after treatment with this nanoparticle. On the other hand, CDKN2B-AS1, LOC102724156, HAGLR and FAM120AOS expression levels were significantly increased in the presence of the aforementioned nanoparticle. After expression level assessment of these 4 lncRNAs in cancer tissue, we founded a significant decreased expression in tumor tissues compared to adjacent normal tissue. Alsibai et al. identified a high positive correlation between levels of expression of $C D K N 2 B-A S 1$ and three tumor suppressor genes. Indeed, they showed an increased expression of, $C D K N 2 B-A S 1$ in invasive colon carcinoma compared to normal tissues [41]. So far, there is no published papers about lncRNAs which are recognized in our study.

\section{Conclusion}

We have used a new data mining method to screen quickly differentially expressed lncRNAs involved in regulation of intrinsic apoptosis pathway in CRC using published gene expression profiling microarrays. Moreover, in vitro assessments were performed to validate and confirm some of these differentially expressed lncRNAs. The present study has successfully demonstrated that the identified lncRNAs are potential therapeutic targets in 


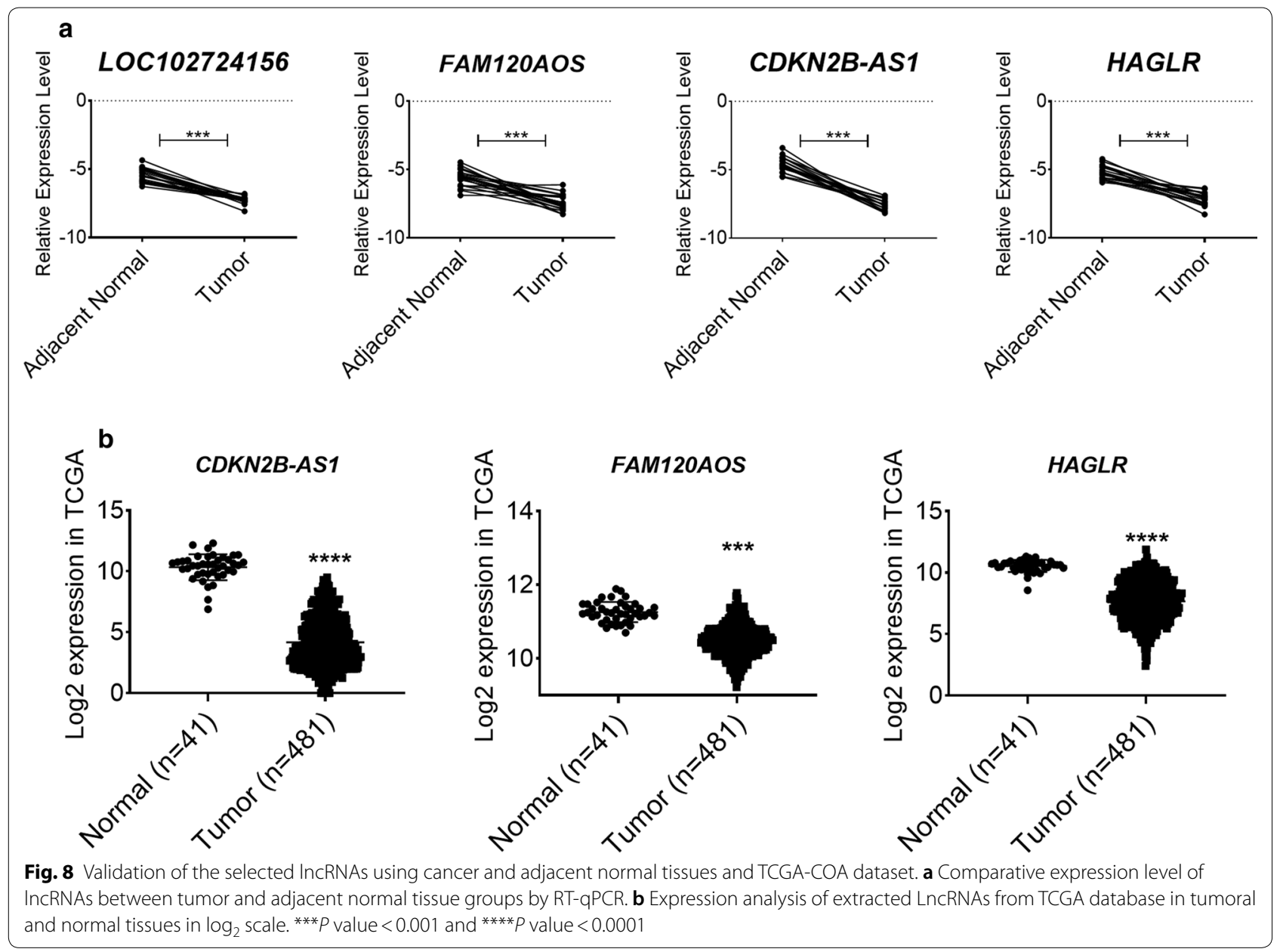

CRC through targeting some intrinsic apoptosis pathway genes.

\section{Supplementary information}

Supplementary information accompanies this paper at https://doi. org/10.1186/s12935-020-01633-w.

Additional file 1: Table S1. List of 48 genes in related to the apoptosis pathway.

Additional file 2: Figure S1. Volcano plot of differential expressed genes (DEGs) between CRC and normal samples from different GSEs based on adj.p-value and $\log _{2}$ (fold-change) at level of 0.0001 and logFC cutoff of 0.5 . Colored dots correspond to individual genes whose expression differences were significant based on both adj.p-value and logFC value (red dots), only p-value (blue dots), only logFC (blue dots), or not significant (green dots) in either.

Additional file 3: Figure S2. The quality control results of two dataset GSE8671 and GSE9348 by utilizing PCA and heatmap.

Additional file 4: Table S2. LncRNAs list with the highest expression correlation with each of the candidate genes.

\section{Abbreviations}

MTT: 3-(4,5-Dimethylthiazol-2yl)-2,5-diphenyltetrazolium bromide; CRC: Colorectal cancer; DEGs: Differentially expression genes; DMSO: Dimethyl sulfoxide; DMEM: Dulbecco's Modified Eagle's Medium; EDX: Energy-dispersive x-ray; FBS: Fetal bovine serum; GEO: Gene Expression Omnibus; GSE: GEO series; IncRNAs: Long noncoding RNAs; NcRNAs: Noncoding RNAs; PCA: Principal component analysis; PI: Propidium iodide; SD: Standard deviation; SEM: Scanning electron microscope; TCGA: The Cancer Genome Atlas; TEM:Transmission electron microscope; TSC: Thiosemicarbazide; XRD: X-ray diffraction.

\section{Acknowledgements}

We thank our colleagues for their association and helpful discussions in this study.

\section{Authors' contributions}

The design and conceptualization of study and methodology was done by $F A$, and MP. Data mining, formal analysis and investigation was performed by FA. Supervision, validation and visualization was done by MP, AS and KG, interpretation of the obtained information was done by MP and AS. The manuscript was written by FA. Review, editing and approved by MP, KG, and AS. All authors read and approved the final manuscript.

Funding

No funding was received. 


\section{Availability of data and materials}

Data sharing not applicable to this article as no data-sets were generated or analyzed during the current study.

\section{Ethics approval and consent to participate}

We obtained the signed informed consent from all patients. This study was approved by the Biomedical Ethics Committee of the Islamic Azad University of Shahrekord and also complies with the Ethics Code of IR.IAU.SHK. REC.1398.044.

\section{Consent for publication}

Not applicable.

\section{Competing interests}

The authors declare that they have no competing interests.

\section{Author details}

${ }^{1}$ Department of Biology, Faculty of Basic Sciences, Shahrekord Branch, Islamic Azad University, Shahrekord, Iran. ${ }^{2}$ Department of Biology, Rasht Branch, Islamic Azad University, Rasht, Iran. ${ }^{3}$ Department of Cell and Molecular Biology and Microbiology, Faculty of Biological Science and Technology, University of Isfahan, Isfahan, Iran.

Received: 22 May 2020 Accepted: 29 October 2020

Published online: 10 November 2020

\section{References}

1. Rawla P, Sunkara T, Barsouk A. Epidemiology of colorectal cancer incidence, mortality, survival, and risk factors. Prz Gastroenterol. 2019;14:89-103.

2. Marley AR, Nan H. Epidemiology of colorectal cancer. Int J Mol Epidemiol Genet. 2016;7(3):105-14.

3. Bray F, Ferlay J, Soerjomataram I, Siegel RL, Torre LA, Jemal A. Global cancer statistics 2018: GLOBOCAN estimates of incidence and mortality worldwide for 36 cancers in 185 countries. CA Cancer J Clin. 2018;2018:68394-424.

4. Plati J, Bucur O, Khosravi-Far R. Dysregulation of apoptotic signaling in cancer: molecular mechanisms and therapeutic opportunities. J Cell Biochem. 2008;104:1124-49.

5. Cheng Y, Geng L, Wang K, Sun J, Xu W, Gong S, Zhu Y. Long noncoding RNA expression signatures of colon cancer based on the ceRNA network and their prognostic value. Dis Mark. 2019;2019:7636757.

6. Bermudez M, Aguilar-Medina M, Lizarraga-Verdugo E, Avendaño-Félix M, Silva-Benítez E, Ramos-Payán R, López-Camarillo C. LncRNAs as regulators of autophagy and drug resistance in colorectal cancer. Front Oncol. 2019;9:1008.

7. Kuleshov MV, Jones MR, Rouillard AD, Fernandez NF, Duan Q, Wang Z, Koplev S, Jenkins SL, Jagodnik KM, Lachmann A, McDermott MG, Monteiro CD, Gundersen GW, Ma'ayan A. A comprehensive gene set enrichment analysis web server 2016 update. Nucleic Acids Res. 2016;44:90-7.

8. Supek F, Škunca M, Rrvigo T, Šmuc T. Summarizes and visualizes long lists of gene ontology terms. PLoS ONE. 2011;6:e21800.

9. Ritchie ME, Phipson B, Wu D, Hu Y, Law CW, Shi W, Smyth GK. limma powers differential expression analyses for RNA-sequencing and microarray studies. Nucleic Acids Res. 2015:43:43-7.

10. Leek JT, Johnson WE, Parker HS, Jaffe AE, Storey JD. The SVA package for removing batch effects and other unwanted variation in high-throughput experiments. Bioinformatics. 2012;28:882-3.

11. Sztupinszki Z, Győrffy B. Colon cancer subtypes: concordance, effect on survival and selection of the most representative preclinical models. Sci Rep. 2016;2016(6):37169.

12. Volders PJ, Anckaert J, Verheggen K, Nuytens J, Martens L, Mestdagh P, Vandesompele J. LNCipedia 5: towards a reference set of human long non-coding RNAs. Nucleic Acids Res. 2019;47:D135-9.

13. Colaprico A, Silva TC, Olsen C, Garofano L, Cava C, Garolini D, Sabedot TS, Malta TM, Pagnotta SM, Castiglioni I, Ceccarelli M, Bontempi G, Noushmehr H. TCGAbiolinks: an R/Bioconductor package for integrative analysis of TCGA data. Nucleic Acids Res. 2016:44:e71.
14. Smoot ME, Ono K, Ruscheinski J, Wang PL, Ideker T. Cytoscape 2.8: new features for data integration and network visualization. Bioinformatics. 2010:27:431-2.

15. Shandiz SAS, Montazeri A, Abdolhosseini M, Shahrestani SH, Hedayati M, Moradi-Shoeili Z, Salehzadeh A. Functionalization of Ag nanoparticles by glutamic acid and conjugation of Ag@Glu by thiosemicarbazide enhances the apoptosis of human breast cancer MCF-7 cells. J Clust Sci. 2018;29:1107-14.

16. Banck MS, Kanwar R, Kulkarni AA, Boora GK, Metge F, Kipp BR, Zhang L, Thorland EC, Minn KT, Tentu R, Eckloff BW, Wieben ED, Wu Y, Cunningham JM, Nagorney DM, Gilbert JA, Ames MM, Beutler AS. The genomic landscape of small intestine neuroendocrine tumors. J Clin Invest. 2013:123:2502-8.

17. Suzuki A, Kusakai G, Kishimoto A, Shimojo Y, Miyamoto S, Ogura T, Ochiai A, Esumi H. Regulation of caspase- 6 and FLIP by the AMPK family member ARK5. Oncogene. 2004;23:7067-75.

18. Farrow SN, Brown R. New members of the Bcl-2 family and their protein parterns. Curr Opin Genet Dev. 1996:6:45-9.

19. Knijn N, Water CVD, Vliet SH, JosMeijer J, Riemersma S, Tebar M, Punt C, Mekenkamp L, Simmer F, Nagtegaal I. Sequencing of RAS/RAF pathway genes in primary colorectal cancer and matched liver and lung metastases. BMC. 2019;39:9.

20. Moorchung N, Kunwar SH, Ahmed KW. An evaluation of nuclear factor kappa B expression in colorectal carcinoma: an analysis of 50 cases. J Cancer Res Ther. 2014;10:631-5.

21. Vlahopoulos S, Adamaki M, Khoury N, Zoumpourlis V, Boldogh I. Roles of DNA repair enzyme OGG1 in innate immunity and its significance for lung cancer. Pharmacol Ther. 2019;194:59-72.

22. Hou H, Sun D, Xiaochun Zhang XI. The role of MDM2 amplification and overexpression in therapeutic resistance of malignant tumors. Cancer Cell Int. 2019;19:216.

23. Wang J, Pendergast AM. The emerging role of $A B L$ kinases in solid tumors. Trends Cancer. 2016;1:110-23.

24. Kaori Sh, Katsuhiko N. Prognostic significance of CDKN2A (p16) promoter methylation and loss of expression in 902 colorectal cancers. Int J Cancer. 2011;128:1080-94.

25. Hartman ML, Czyz M. BCL-w: apoptotic and non-apoptotic role in health and disease. Cell Death Dis. 2020;11:260.

26. D'Atri S, Tentori L, Lacal PM, Graziani G, Pagani E, Benincasa E, Zambruno G, Bonmassar E, Jiricny J. Involvement of the mismatch repair system in temozolomide-induced apoptosis. Mol Pharmacol. 1998;54:334-41.

27. LiY, Wei J, Xu C, Zhao Z, You T. Prognostic significance of cyclin D1 expression in colorectal cancer: a meta-analysis of observational studies. PLoS ONE. 2014;9:e94508.

28. Yifeng FA, Xiao LI. miR-424 targets AKT3 and PSAT1 and has a tumorsuppressive role in human colorectal cancer. Cancer Manag Res. 2018;10:6537-47.

29. Wee HJ, Voon DC, Bae SC, Ito Y. PEBP2- $\beta / C B F-\beta$-dependent phosphorylation of RUNX1 and p300 by HIPK2: implications for leukemogenesis. Blood. 2008;112:3777-87.

30. Jansson AK, Emterling AM, Arbman G, Sun XF. Noxa in colorectal cancer: a study on DNA, mRNA and protein expression. Oncogene. 2003:22:4675-8.

31. Acehan D, Jiang X, Morgan DG, Heuser JE, Wang X, Akey CW. Threedimensional structure of the apoptosome: implications for assembly, procaspase-9 binding, and activation. Mol Cell. 2002;9:423-32.

32. Jin $L$, Wang Y. Surface chemistry of methanol on different $\mathrm{ZnO}$ surfaces studied by vibrational spectroscopy. PCCP. 2017;19:12992-3001.

33. Barick KC, Sharma A, Neena G, Ningthoujam RS, Vatsa RK, Babu PD, Pandey $\mathrm{BN}$, Hassan PA. Covalent bridging of surface functionalized $\mathrm{Fe}_{3} \mathrm{O}_{4}$ and $\mathrm{YPO}_{4}$ : Eu nanostructures for simultaneous imaging and therapy. Dalton Trans. 2015:44:14686-96.

34. Elmore S. Apoptosis: a review of programmed cell death. Toxicol Pathol. 2007;35:495-516

35. Zhang Y, Chen X, Gueydan C, Han J. Plasma membrane changes during programmed cell deaths. Cell Res. 2018;28:9-21.

36. Li J, Yuan J. Caspases in apoptosis and beyond. Oncogene. 2008;27:6194-206. 
37. Fulda S, Debatin KM. Extrinsic versus intrinsic apoptosis pathways in anticancer chemotherapy. Oncogene. 2006;25:4798-811.

38. Choudhury S. A comparative analysis of $B C L-2$ family. Bioinformation. 2019;15:299-306.

39. Pfeffer CM, Singh ATK. Apoptosis: a target for anticancer therapy. Int J Mol Sci. 2018;19:448.

40. Siddiqui $\mathrm{H}$, Ghafari $\mathrm{A}$, Choudhry $\mathrm{H}, \mathrm{Al} \mathrm{DH}$. Roles of long non-coding RNAs in colorectal cancer tumorigenesis. Mol Clin Oncol. 2019;11:167-72.

41. Alsibai K, Vacher S, Meseure D, Nicolas A, Lae M, Schnitzler A, Chemlali W, Cros J, Longchampt E, Cacheux W, Pignot G, Callens C, Pasmant E, Allory
Y, Bieche I. High positive correlations between ANRIL and p16-CDKN2A/ p15-CDKN2B/p14-ARF gene cluster overexpression in multi-tumor types suggest deregulated activation of an ANRIL-ARF bidirectional promoter. Noncoding RNA. 2019;5:44.

\section{Publisher's Note}

Springer Nature remains neutral with regard to jurisdictional claims in published maps and institutional affiliations.
Ready to submit your research? Choose BMC and benefit from:

- fast, convenient online submission

- thorough peer review by experienced researchers in your field

- rapid publication on acceptance

- support for research data, including large and complex data types

- gold Open Access which fosters wider collaboration and increased citations

- maximum visibility for your research: over $100 \mathrm{M}$ website views per year

At BMC, research is always in progress.

Learn more biomedcentral.com/submissions 